\title{
Mayer-Rokitansky-Küster-Hauser syndrome
}

\author{
Elsy Thomas, ${ }^{1}$ Sahana Shetty, ${ }^{2}$ Nitin Kapoor, ${ }^{2}$ Thomas Vizhalil Paul ${ }^{2}$
}

${ }^{1}$ Department of Obstetrics and Gynaecology, Christian Medical College, Vellore, Tamil Nadu, India

${ }^{2}$ Department of Endocrinology, Christian Medical College, Vellore, Tamil Nadu, India

\section{Correspondence to} Professor Thomas Vizhalil Paul, thomasvpaul@yahoo.com

Accepted 24 April 2015

\section{DESCRIPTION}

A 19-year-old female patient presented with a history of primary amenorrhoea. Her developmental milestones were normal. There was no history of systemic illness or chronic medication use. She noticed thelarche at the age of 11 years and developed pubic hair at 13 years. She was born as the first child to second degree consanguinity and her younger sibling (sister) had attained menarche at 12 years of age. There was no growth stunting. On examination, she was $159 \mathrm{~cm}$ tall (with a midparental height of $162 \mathrm{~cm}$ ) and had normal appearing female external genitalia and breasts (Tanner stage-5) and also had normal axillary and pubic hair development. There were no dysmorphic features. Her karyotyping was normal $(46, \mathrm{XX})$. The patient blood investigations were as follows: haemoglobin $13.8 \mathrm{~g} / \mathrm{dL}$ (normal range12-15), serum creatinine $0.8 \mathrm{mg} / \mathrm{dL}$ (normal range0.6-1.2), follicle stimulating hormone $4.2 \mathrm{mIU} / \mathrm{mL}$ (normal range $0-4.5$ ), luteinising hormone $8.9 \mathrm{mIU} / \mathrm{mL}$ (normal range 1.9-12.5), testosterone $38.2 \mathrm{ng} / \mathrm{dL}$ (normal range 50-120), anti-Müllerian hormone $6 \mathrm{ng} / \mathrm{mL}$ (normal range 2-6.8), oestradiol $160 \mathrm{pg} / \mathrm{mL}$ (normal range 30-400) and 17-hydroxyprogesterone $80 \mathrm{ng} / \mathrm{dL}$ (normal range $<100$ ).

An axial section of the MRI of the abdomen and pelvis showed complete absence of uterus, cervix and vagina, with normal ovaries. (figure 1). A coronal section displayed a single midline pelvic pancake kidney (figure 2). There were no vertebral body anomalies. A diagnosis of Mayer-RokitanskyKüster-Hauser (MRKH) syndrome was made. MRKH syndrome is typically known by the congenital absence of the uterus and the upper part of the vagina in women who have normally developed secondary sexual characters along with a normal female 46,XX karyotype. The reported incidence is about 1 in 4000-5000 live births. They are usually sporadic, although familial cases have also been described, denoting a probable genetic cause. ${ }^{1}$ Affected women have normal growth and pubertal development

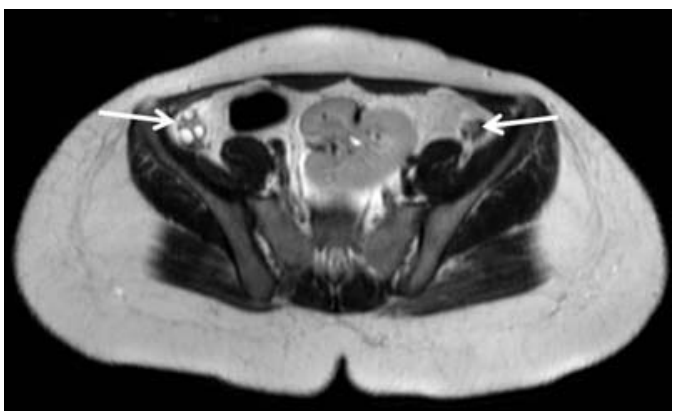
Month Year] doi:10.1136/
Figure $1 \mathrm{MRI}$ of the abdomen and pelvis (axial section) showing complete absence of uterus, cervix and vagina, with normal ovaries.
Shetty $S$, Kapoor N, et al BMJ Case Rep Published online: [please include Day bcr-2015-210187

CrossMark

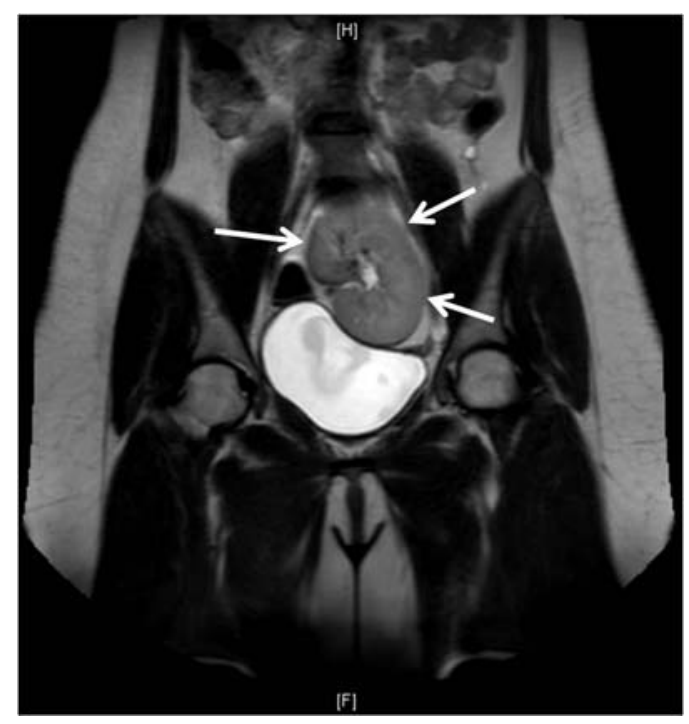

Figure 2 MRI of the pelvis (coronal section) displaying a single midline pelvic pancake kidney.

(normal breast and pubic as well as axillary hair development in the presence of primary amenorrhoea). This condition is also usually associated with renal defects (unilateral agenesis or ectopia of 1 or both kidneys, horseshoe kidney in $40 \%$ of patients), cervicothoracic anomalies (asymmetric, fused vertebrae, scoliosis and Klippel-Feil anomaly in about onefifth). Biochemical evaluation is essentially normal as these patients have normal functioning ovaries. Management of this condition includes screening for associated renal and skeletal anomalies. Psychological counselling and surgical procedures to create a neovagina when the patient is ready to start sexual activity are the main modalities of treatment for $\mathrm{MRKH}$ syndrome. ${ }^{2}$

\section{Learning points}

- Mayer-Rokitansky-Küster-Hauser (MRKH) syndrome is diagnosed when a woman presents with primary amenorrhoea along with development of normal secondary sexual characters and normal female XX karyotype.

- MRKH syndrome is characterised by the congenital aplasia of the uterus and upper part of the vagina.

- Associated conditions such as ectopic or pelvic kidneys and skeletal deformities are seen in at least one-fourth of the patients.

Acknowledgements The authors thank Banu Shankar for secretarial help. 


\section{Images in...}

Contributors ET and SS wrote the manuscript. NK and TVP reviewed the manuscript. All the authors approved the final manuscript.

Competing interests None declared.

Patient consent Obtained.

Provenance and peer review Not commissioned; externally peer reviewed.

\section{REFERENCES}

1 Guerrier D, Mouchel T, Pasquier L, et al. The Mayer-Rokitansky-Küster-Hauser syndrome (congenital absence of uterus and vagina)-phenotypic manifestations and genetic approaches. J Negat Results Biomed 2006;5:1.

2 Morcel K, Camborieux L, Guerrier D; Programme de Recherches sur les Aplasies Müllériennes. Mayer-Rokitansky-Küster-Hauser (MRKH) syndrome. Orphanet J Rare Dis 2007;2:13.

Copyright 2015 BMJ Publishing Group. All rights reserved. For permission to reuse any of this content visit http://group.bmj.com/group/rights-licensing/permissions.

BMJ Case Report Fellows may re-use this article for personal use and teaching without any further permission.

Become a Fellow of BMJ Case Reports today and you can:

- Submit as many cases as you like

- Enjoy fast sympathetic peer review and rapid publication of accepted articles

- Access all the published articles

- Re-use any of the published material for personal use and teaching without further permission

For information on Institutional Fellowships contact consortiasales@bmjgroup.com

Visit casereports.bmj.com for more articles like this and to become a Fellow 